\title{
Source Identification of VOCs and their Environmental Health Risk in a Petrochemical Industrial Area
}

\author{
Nattaporn Pinthong ${ }^{1}$, Sarawut Thepanondh ${ }^{1,2^{*}}$, Akira Kondo ${ }^{3}$ \\ ${ }^{1}$ Department of Sanitary Engineering, Faculty of Public Health, Mahidol University, Bangkok, \\ 10400, Thailand \\ ${ }^{2}$ Center of Excellence on Environmental Health and Toxicology (EHT), Bangkok 10400, Thailand \\ ${ }^{3}$ Graduate School of Engineering, Osaka University, Osaka 565-0871, Japan
}

\section{ABSTRACT}

Ambient VOCs in the vicinity of a petrochemical industrial area were analyzed for their health impact and potential emission sources. Comprehensive measurements of VOCs were conducted based on U.S. EPA TO-15. Potential carcinogenic and non-carcinogenic inhalation risks were evaluated by comparing the measured concentrations with the inhalation unit risk (IUR) and reference concentration $(\mathrm{RFC})$. The results indicated that a high carcinogenic risk occurred from 1,2 dibromoethane and benzene, while non-carcinogenic risks were attributed to 1,3 butadiene, 1,1,2 trichloroethane, and 3-chloropropene. The Positive Matrix Factorization (PMF) Version 5.0 was further utilized to estimate the contribution of specific sources to the VOC mixing ratio. The results revealed that the average VOC concentration in the community area was dominated by aromatic hydrocarbons, with toluene having the highest concentration. Vehicle exhaust was evaluated as the most contributing emission source of the VOC mixing ratio, followed by industrial processes. Specific VOC ratios were also applied to identify VOC sources. The T/B ratio was within the range 3.54-5.15, confirming that vehicle emissions were the main source of pollutants during the entire investigated period in the community area. As for the industrial area, the average VOC concentration was dominated by alkenes. Industrial processes and the petrochemical industry were the major sources of VOCs. The health risk assessment in the industrial area indicated that acrolein had the highest risk for non-carcinogens. 1,2-dichloroethane and 1,3-butadiene showed high potential as carcinogens.

Received: March 24, 2021

Revised: December 17, 2021

Accepted: January 6, 2022

Keywords: Diagnostic ratio, Health risk assessment, Map Ta Phut, Source apportionment, Volatile organic compound (VOCs)

\section{${ }^{*}$ Corresponding Author:}

sarawut.the@mahidol.ac.th

\section{Publisher:}

Taiwan Association for Aerosol Research

ISSN: $1680-8584$ print ISSN: 2071-1409 online

\section{Copyright: The Author(s).} This is an open access article distributed under the terms of the Creative Commons Attribution License (CC BY 4.0), which permits unrestricted use, distribution, and reproduction in any medium, provided the original author and source are cited.

\section{INTRODUCTION}

It is well recognized that rapid urban and industrial development are major factors leading to an increase in air pollution. The detrimental impacts of air pollution can occur in both human health and the environment (Dumanoglu et al., 2014; Zhang et al., 2014; Dorter et al., 2020). Volatile organic compounds (VOCs) have been widely considered as one of the major air pollutants owing to their direct and indirect impacts. VOCs were defined by the World Health Organization (WHO) as organic compounds, having a boiling point within the range $50^{\circ} \mathrm{C}-260^{\circ} \mathrm{C}$ and vapor pressure $>10 \mathrm{~Pa}$ at ambient temperature (WHO, 1989; Dorter et al., 2020). The photochemical interactions among VOCs and nitrogen oxide $\left(\mathrm{NO}_{x}\right)$ lead to the formation of tropospheric ozone $\left(\mathrm{O}_{3}\right)$ and other secondary pollutants, including peroxyacetyl nitrate (PAN) and secondary organic aerosol (SOA) (Carter, 1994; Leuchner and Rappengluck, 2010; Wu et al., 2016). These secondary air pollutants receive a great deal of attention because of their potential environmental and health impacts (Hui et al., 2019; Li et al., 2020; Mozaffar et al., 2020). 
Emission sources of VOCs include both anthropogenic and biogenic sources (Huang et al., 2015). Generally, vehicular exhaust and industrial sources are the major anthropogenic sources (Caselli et al., 2010; Ling and Guo, 2014; Zhang et al., 2017). Moreover, VOCs can be released from household products and pesticides (U.S. EPA, 2017b).

Identification of the sources of VOCS can be undertaken by the application of receptororiented models (Duodu et al., 2017; Song et al., 2019; Jain et al., 2018; Li et al., 2018). The positive matrix factorization (PMF) model was developed by Paatero (Paatero and Tapper, 1993; 1994) and has become one of the most widely used for source apportionment, following its recommendation by the U.S. EPA (Hopke, 2016). PMF is a tool of multivariate factor analysis that decomposes a matrix of specified sample data into two matrices, namely factor contributions (G) and factor profiles (F). This technique is used to derive a set of source composition profiles, each of which identifies a mixture of compounds associated with a particular emission category. Several studies have applied PMF to determine the potential emission sources of VOCs (Bari et al., 2018; Li et al., 2018, Liu et al., 2020; Li et al., 2021, Xuan et al., 2021).

Health risk assessment is one of the tools for estimating the nature and probability of adverse health effects on people exposed now or in the future to chemicals in contaminated environmental media and for determining the level of treatment needed to address a particular problem. The health risks of VOCs have been reported in epidemiological studies (Jiang et al., 2016; Zhao et al., 2019, Yang et al., 2019; Xiong et al., 2020; Liu et al., 2021). Some VOCs, including benzene, vinyl chloride, 1,3-butadiene, trichloroethylene, and 1,2-dichloropropane, have been classified as carcinogens by the International Agency for Research on Cancer (IARC, 2020).

Previous studies have applied the PMF model and health risk assessment method to evaluate the potential sources and health risk of VOC pollutants. For example, Zheng et al. (2020) reported that the main sources of VOCs are fuel evaporation, industrial sources, ethylene industry, and regional background. Acrolein and 1,3-butadiene had the highest non-carcinogenic risk and the highest carcinogenic risk in the petrochemical industry in Wuhan, China. Li et al. (2020) identified the major sources of VOCs and evaluated their health risk in Zhengzhou, China. The result revealed that the main source of VOCs was solvent utilization, followed by industrial production, long-lived and secondary species, vehicle emissions, and biogenic emission. None of the VOC species posed a non-carcinogenic risk, but five of them had a carcinogenic risk to the exposed population.

Since VOCs are emitted from a variety of sources and can affect human health. The rapid development of industry causes many environmental and health problems in the area. The results of previous studies indicate that VOC monitoring stations do not fully represent the impact of industrial emissions and the health risk assessment of VOCs in the environment is limited. VOC source identification and health risk assessment would facilitate the development of appropriate and effective control strategies. Findings in other studies are integrated together in this research to be the first attempt in Thailand to evaluate the source and health risk of ambient VOC in the petroleum and petrochemical estate. Comprehensive analysis of the entire potential VOCs emitting activities are intensively analyzed which make it differs from other studies when only single source/factory is considered. To support and advocate the policy in managing industrial air pollution, The Map Ta Phut industrial complex, which is the largest petroleum and petrochemical industrial complex in Thailand, was selected as the study area. This area has suffered from concentrations of ambient VOCs, including 1,2-dichloroethane, benzene, and 1,3-butadiene, that exceed the Thai annual standard (PCD, 2018). The results obtained from this comprehensive study will be very useful for managing and controlling area-based air pollution. The findings and methodology demonstrated in this study can be used to elucidate the source and effect of air pollution in other environmental studies.

\section{METHODOLOGY}

\subsection{Study Area}

The Map Ta Phut industrial complex is in Rayong Province, East Thailand (approximately $130 \mathrm{~km}$ east of Bangkok). In 1990, the Thai government officially opened the Map Ta Phut industrial estate, the largest industrial park of the country focused on the petrochemical industry and related sectors. The area would rapidly grow and today it houses five industrial estates, one deep-sea port, 


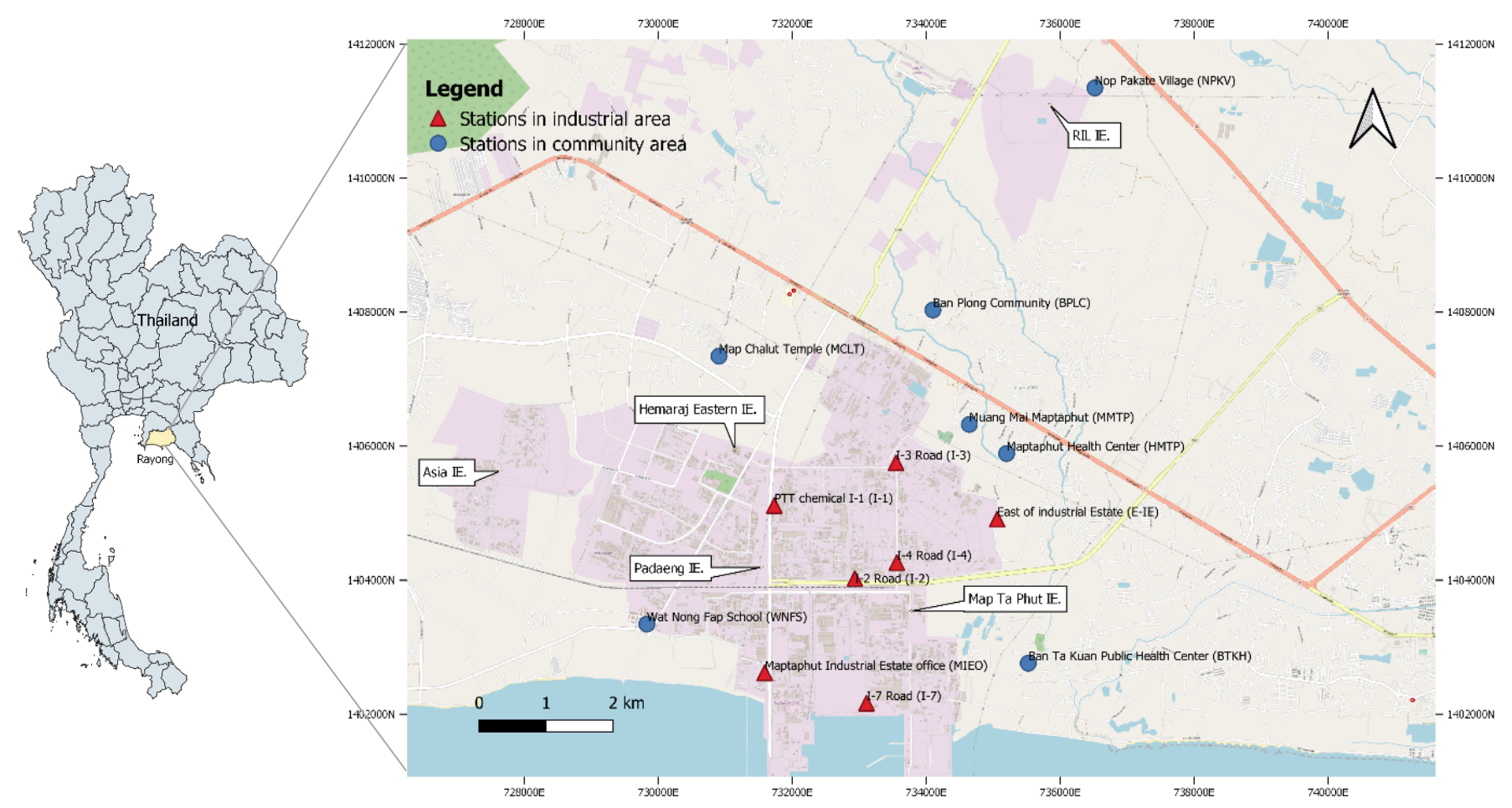

Fig. 1. Location of the study area, and VOCs sampling sites (IE = Industrial estate).

and 151 major factories, including petrochemical plants, petroleum refineries, coal-fired power stations, and iron and steel facilities (Thepanondh et al., 2011). Concern on industrial pollution has been raised by the public, particularly with the issue related to air pollution (Hanma et al., 2021). High concentrations of carcinogenic VOCs (benzene, 1,2-dichloroethane, and 1,3-butadiene) were occasionally detected in the community areas.

In this study, comprehensive monitoring of VOCs was conducted within industrial and community zones. The seven monitoring stations in the industrial area were MIEO, I-4, I-3, E-IE, I-2, I-7, and I-1. Twenty VOC compounds were measured at these sites.

Monitoring sites of VOCs in the community areas were HMTP, BTKH, WNFS, MMTP, MCLT, BPLC, and NPKV. There were located covering all direction from industrial complex. Distance to the main road of HMTP, BTKH, WNFS, MMTP, MCLT, BPLC, and NPKV are 0.64, 3.23, 0.02, 0.29, 1.550 .63 , and $0.62 \mathrm{~km}$, respectively, and distance from Map Ta Phut Complex are 0.62, 0.98, $1.50,0.32,1.68,0.08$, and $0.22 \mathrm{~km}$, respectively. Forty-three VOCs were identified and reported monthly for these stations. The spatial distribution of the monitoring sites is shown in Fig. 1.

\subsection{Data Collection}

Comprehensive measurements were conducted monthly from January 2012 to December 2016. Sampling of ambient VOC concentrations was carried out using 6-liter evacuated canisters $(0.05 \mathrm{~mm} \mathrm{Hg}$ ) for $24 \mathrm{~h}$. Samples were analysed in the laboratory using a gas chromatography/mass spectrophotometer (GC/MS) based on the U.S. EPA TO-15. Details of the sampling and analytical procedures are presented elsewhere (Jindamanee et al., 2020; Saikomol et al., 2019; Thepanondh et al., 2011).

Quality assurance and quality control (QA/QC) procedures was implemented to ensure the quality of data. Before sampling, all canisters were cleaned by pressurizing with nitrogen, adding pure water to prevent VOCs adsorption to the inside wall and tested the samples as blank samples to confirm their cleanliness. Samples were transferred from canister to the preconcentration unit which concentrating and minimizing sample volume to be injected into the Chromatograph Mass Spectrophotometer (GC/MS). The air samples were drawn through the heated sampling line to remove moisture and control of the flow rate of the sampling (Saikomol et al., 2019). The duplicate precision was estimated by calculating the percentage difference of sample concentration 
and duplicate sample concentration, with less than $25 \%$. For the compounds detected in blanks, the detection limit (MDL) and the method limit of quantitation (MQL) were defined as the results of the calculation by multiplying the standard deviation of field blank values with three and ten, respectively. Quality of the measured data were assured through the QA/QC criteria strictly conducted under this study. The acceptance criteria of the correlation coefficients from the calibration curves were above 0.99 . The relative standard deviation values were below $20 \%$ and were used in the judgment of the calibration. Method determination (MDL) was determined for each compound and ranged from 0.002 to $0.05\left(\mu \mathrm{g} \mathrm{m}^{-3}\right)$. Totally, there were 22,880 measured VOCs concentrations passed these criteria and be used in this study.

\subsection{VOCs Diagnostic Ratio}

The diagnostic ratio of BTEX (benzene, toluene, ethylbenzene, and xylene) has been used in several studies to identify the emission sources and the age of the air mass of pollution (Masih et al., 2016; Miri et al., 2016; Phuc and Kim Oanh, 2018). The toluene-to-benzene (T/B) concentration ratio is typically used as a tracer to evaluate traffic emissions. $T / B$ in the range $1.5-4.3$ represents a traffic-originated emission source (Alfoldy et al., 2019; Golkhorshidi et al., 2019; Kumar et al., 2018; Miller et al., 2012), while a ratio exceeding 10 indicates the influence of industrial sources (Kumar et al., 2018; Tohid et al., 2019; Xiong et al., 2020). Tohid et al. (2019) reported that the T/B ratio of $0.13-0.71$ and $0.23-0.68$ were representative of the contribution from coal combustion and biomass burning, respectively. In addition, the ratios of $x y l e n e /$ benzene $(X / B)$, xylene/ethylbenzene $(X / E B)$, and ethylbenzene/benzene $(E B / B)$ can be used to indicate the age of an air mass and photochemical reactivity in ambient air. $A$ ratio of $X / B$ and $E B / B$ exceeding 1.1, indicates a fresh air mass due to a lack of hydroxyl radicals $(\cdot \mathrm{OH})$ reacting with isomers of ethylbenzene and xylene during daytime (Golkhorshidi et al., 2019; Liu et al., 2008). However, m,p-X/B values lower than 1.8 , and $\mathrm{O}-\mathrm{X} / \mathrm{B}$ values lower than 0.9 , are also considered as indicative of vehicular emission sources (Cruz et al., 2020).

In this study, the Statistical Package for the Social Sciences (SPSS) analytical software version 21 was used for statistical analysis. The relationship between the BTEX compound at each monitoring station was assessed using Spearman's rank correlation coefficient. The correlation was significant at the 0.01 level (2-tailed). The ratios of $T / B, X / B, X / E B$, and EB/B were analyzed to identify the emission source of the target compound, as well as their photochemical aging.

\subsection{VOCs Source Identification}

Several methods have been applied to identify the emission sources of VOCs, including emission inventory (Fu et al., 2020), dispersion models (Song et al., 2019), ratios between specific VOCs (Tan et al., 2020), and receptor models (Ling et al., 2011). Establishing the emission inventory for pollutants in specific area is often time and resource consuming. Uncertainty of the emission inventory is greatly influenced to the performance of the dispersion model. In addition, meteorological data is a required input, the terrains and atmospheric conditions can affect to the modelling results. Unfortunately, in many areas these local data are not available. To overcome this limitation, measured ambient air concentrations at the receptors have been used to identify for their potential emission sources through the application of the receptor-oriented models. Receptor models such as positive matrix factorization (PMF) model, principal component analysis (PCA), chemical mass balance (CMB) model, and UNMIX model have been extensively used to identify sources of VOCs. Among them, PMF has some advantage over other models. The main advantage is that it can individually weight each data point. PMF does not requires comprehensive advance information on source compositions to be able to interpret the results and the non-negativity constraint in PMF is advantage. Ratios between specific VOCs can be initially seek pollutant sources to confirm the results from receptor models.

PMF is a receptor model used to indicate the source profile and source contribution of pollutants through multivariate factor analysis (Shao et al., 2016). Two input files (concentration and uncertainty files) are required to run the model. Details of the PMF model have been described elsewhere (Paatero and Tapper, 1993, 1994; U.S. EPA, 2014). In this study, the PMF model (v.5) was used to quantify the contribution of potential emission sources of VOCs. The mass balance equation of PMF can be expressed as follows: 
$x_{i j}=\sum_{k=1}^{p} g_{i k} f_{k j}+e_{i j}$

where, $x_{i j}$ is the $j_{t h}$ species concentration measured in the $i_{\text {th }}$ sample, $g_{i k}$ is the species contribution of the $k_{t h}$ source to the $i_{t h}$ sample, $f_{k j}$ is the $j_{t h}$ species fraction from the $k_{t h}$ source, $e_{i j}$ is the residual matrix information of the $j_{\text {th }}$ species for the $i_{\text {th }}$ sample and $p$ is the total number of independent sources (Paatero, 1993).

Factor contributions and profiles are derived by the PMF model minimizing the objective function $Q$ as follows:

$Q=\sum_{i=1}^{n} \sum_{j=l}^{m}\left[\frac{x_{i j}-\sum_{k=1}^{p} g_{i k} f_{k j}}{u_{i j}}\right]$

where, $u_{i j}$ is the uncertainty information of the $j_{t h}$ species from the $i_{t h}$ sample.

The missing concentration data were replaced by the geometric mean of the detected concentration while the uncertainty file was prepared following the recommendation from U.S EPA (U.S. EPA, 2014). Additionally, where more than $25 \%$ of missing data occurred, or data values were lower than the method detection limit, (MDL), these compounds were rejected from the PMF analysis in this study.

For model input, the uncertainty data was calculated based on USEPA FMF user guide. The concentration sample data uncertainty is calculated using the following equation.

Unc $=\sqrt{(\text { Error Fraction } \times \text { concentration })^{2}+(0.5 \times M D L)^{2}} \quad($ conc $>M D L)$

Otherwise, the data concentration is below or equal to MDL provided, Eq. (4) is adopted.

Unc $=\frac{5}{6} \times M D L \quad($ conc $\leq M D L)$

where, MDL represents the method detection limit, error fraction. The error fraction in this study was $10 \%$.

The model was run 20 times with a random seed to determine the stability of $Q$ values and the source profile result can be interpreted. To determine the optimal number of sources, the $\mathrm{Q}$ (robust)/Q (true) ratio must be less than 1.5 for the result to be accepted (Chen et al., 2019) and results are the most physically reasonable explanations. VOC species were divided into three categories according to signal-to-noise ratios $(\mathrm{S} / \mathrm{N})$ and $\mathrm{BDL}$ (Below Detection Limit) percentages that were calculated to evaluate the quality of species data. According to the U.S. EPA user guide, the species were divided as "strong" if the $\mathrm{S} / \mathrm{N}$ ratio is $>2$, "weak" if the $\mathrm{S} / \mathrm{N}$ ratio is $>0.2$ but $<2$ or the BDL percentage is $>50 \%$ and "bad" if the $\mathrm{S} / \mathrm{N}$ ratio is $<0.2$ or the BDL percentage is $>60 \%$. According to these rules, all VOC species grouped into strong category.

\subsection{Risk Assessment}

A standard health risk assessment method recommended by the United States Environmental Protection Agency (U.S. EPA) was applied to estimate the potential harmful health risks (carcinogenic and non-carcinogenic risks) of VOCs. The concentrations of each compound were re-calculated to generate exposure concentrations prior to use for further assessment of health risk following the equation recommended by the U.S. EPA (2009) as follows.

$E C i=(C A i \times E T \times E F \times E D) / A T$

where, $E C$ is the exposure concentration $\left(\mu \mathrm{g} \mathrm{m}^{-3}\right)$ of chemical $i$; CAi is the contaminant 
Table 1. Parameters used in calculation of exposure concentration.

\begin{tabular}{|c|c|c|c|c|}
\hline \multirow{2}{*}{ Variable } & \multirow{2}{*}{ Description } & \multicolumn{2}{|c|}{ value } & \multirow{2}{*}{ Units } \\
\hline & & Community area & Industrial area & \\
\hline ET & Daily exposure time & 24 & 8 & hour day ${ }^{-1}$ \\
\hline $\mathrm{EF}$ & Exposure frequency & 365 & 250 & day year ${ }^{-1}$ \\
\hline ED & exposure duration & 70 & 25 & year \\
\hline AT & averaging time & $613200^{a}$ & $219000^{b}$ & hour \\
\hline
\end{tabular}

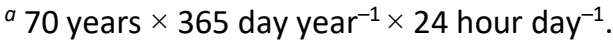

${ }^{b} 25$ years $\times 250$ day year ${ }^{-1} \times 24$ hour day $^{-1}$.

concentration $\left(\mu \mathrm{g} \mathrm{m}^{-3}\right.$ ) of chemical $i$ in ambient air; $E T$ is the daily exposure time (hours per day); $E F$ is the exposure frequency (days per year); $E D$ is the exposure duration during a lifetime (years); and $A T$ is the averaging time (ED $\times 365 \mathrm{~d} \mathrm{y}^{-1} \times 24 \mathrm{~h} \mathrm{~d}^{-1}$, hours). The variables are presented in Table 1.

Non-carcinogenic risk was estimated by the hazard quotient $(\mathrm{HQ})$ and hazard index $(\mathrm{HI})$ of the same target organ system according to the dose-response relationship. Therefore, the HQ of each compound (i) was estimated as the ratio of exposure concentration (ECi) to the reference concentration $(R f C i)$. The hazard quotient $(\mathrm{HQ})$ for non-carcinogenic risk was calculated as follows:

$H Q=E C i / R f C i \times 1000$

$\mathrm{HI}$ is the sum of the hazard quotients of toxic air pollutants that can affect humans on the same target organ system. In this study, $\mathrm{HI}$ of respiratory, hematologic, nervous, cardiovascular, reproductive, developmental, alimentary, kidney, urinary, and eye systems at each monitoring station were calculated for chronic health effects in non-cancer patients. $\mathrm{HI}$ is calculated as the sum of the HQs of the target organ. For non-carcinogenic compounds, it is common to consider the risk to be negligible if the $\mathrm{HI}$ is less than or equal to 1.0, while an $\mathrm{HI}$ exceeding 1.0 signifies an appreciable risk of human health effects (U.S. EPA, 2009).

For the carcinogenic risk, the risk value for a single carcinogenic compound via inhalation exposure was calculated by multiplying the exposure concentration (ECi) by the inhalation unit risk (IURi). The risk characterization for a single carcinogenic compound is expressed as follows:

Risk $=E C i \times I U R i$,

where IURi is the inhalation unit risk $\left(\mathrm{m}^{3} \mu \mathrm{g}^{-1}\right)$ of chemical $i$, which is the upper-bound excess lifetime cancer risk estimated to result from continuous exposure to an agent at a concentration of $1 \mu \mathrm{g} \mathrm{m}^{-3}$ in air. The risk predicted to be less than or equal to $1 \times 10^{-6}$ is usually considered negligible, whereas the risk predicted to exceed or equal $1 \times 10^{-3}$ was defined as a significant risk (Rodricks et al., 1987). The RfC and IUR values of each VOC were obtained from the Integrated Risk Information System (IRIS). In cases where there is no available information on the IRIS database, the values offered by the Provisional Peer Reviewed Toxicity Values (PPRTV), California Environmental Protection Agency (CALEPA), Health Effects Assessment Summary Tables (HEAST), and Agency for Toxic Substances and Disease Registry (ATSDR), were used in this study.

\section{RESULTS AND DISCUSSION}

\subsection{Characteristics of Airborne VOCs}

In the community area, 40 VOC species were analyzed at each monitoring station. Total VOC concentrations were in the range $23.07-50.31 \mathrm{~g} \mathrm{~m}^{-3}$. Aromatic hydrocarbons was the dominant group (13.26-39.79 $\left.\mathrm{g} \mathrm{m}^{-3}\right)$, followed by halogenated hydrocarbons $\left(9.65-14.0 \mu \mathrm{g} \mathrm{m}^{-3}\right.$ ) and alkenes $\left(0.13-0.92 \mu \mathrm{g} \mathrm{m}^{-3}\right)$. Toluene had the highest concentration $\left(5.53-24.61 \mu \mathrm{g} \mathrm{m}^{-3}\right)$ at every monitoring stations. High concentrations of toluene, $m-, p-x y l e n e$, benzene, and ethylbenzene were detected as the top ten VOCs in this area. These VOCs are typically emitted from traffic and industrial processes (Dumanoglu et al., 2014; Hui et al., 2018; Xie and Berkowitz, 2006; McCarthy, 2013). 
The average concentrations of 20 VOCs in the industrial area ranged within $17.21-81.80 \mu \mathrm{g} \mathrm{m}^{-3}$, with alkene accounting for $4.0-60.69 \%$ of the VOC mixing ratios $\left(0.69-40.53 \mu \mathrm{g} \mathrm{m}^{-3}\right)$. The second dominant group was aromatic hydrocarbons, which ranged between $2.01-12.00 \mu \mathrm{g} \mathrm{m}^{-3}(11.68-$ $27.99 \%)$ follow by halogenated hydrocarbons $\left(5.21-33.33 \mu \mathrm{g} \mathrm{m}^{-3} ; 26.84-74.78 \%\right)$, aldehydes (5.45$\left.11.34 \mu \mathrm{g} \mathrm{m}^{-3} ; 31.67-26.45 \%\right)$, and others (1.07-1.75 $\left.\mu \mathrm{g} \mathrm{m}^{-3} ; 2.50-2.62 \%\right)$. High concentrations of 1,3-butadiene and acetaldehyde were detected within the industrial area. High concentrations of 1,3-butadiene can be found in highly industrialized cities or near oil refineries, chemical manufacturing plants, and plastic and rubber factories, while acetaldehyde is used as an intermediate in the synthesis of other chemicals and used in the production of polyester resins (ATSDR, 2020; U.S. EPA, 2017a).

In community area seasonal variations showed that VOC concentration was higher in the dry (November-April) season than in the wet (May-October) season at all stations which may be due to increasing of evaporated VOCs from potential source at higher air temperatures in dry season and their ability to disperse in a longer distance from their emission sources in the dry season. This is confirmed by the finding within the overall industrial area where VOCs concentrations were higher in the wet season than in the dry season expect at the I-7 station. Seasonal variation of VOCs concentrations at each monitoring station in community area and within industrial area are shown in Figs. S1 and S2, respectively. There is no temporal difference of VOC concentrations in different years. Inter-annual variation of total VOCs concentration in different monitoring station in 2012-2016 in community area and within industrial area are shown Figs. S4 and S5, respectively.

\subsection{Identification of Potential VOCs Emission Sources}

\subsubsection{In the community area}

In the community area, 40 VOC species were applied in the PMF model, and the results of 11 factors were grouped according to the percentage of tracer species in each emission source. The factors associated with a high percentage of benzene, total xylene, and ethylbenzene, which are the key tracers of gasoline combustion in mobile motors, were identified as vehicle source emissions (Bozkurt et al., 2018; Dumanoglu et al., 2014; Guo et al., 2011; Ling et al., 2014). 1,3,5trimethylbenzene, and 1,2,4-trimethylbenzene have been demonstrated to be good tracers for diesel vehicle emissions (Bozkurt et al., 2018; Huang et al., 2017). In the PVC industry, vinyl chloride and 1,2-dichloroethane are used as raw materials. Therefore, these VOCs are the major signature of this industrial group. Industrial origins probably emitted toluene, styrene, and 1,3-butadiene. Accordingly, these VOCs are a signature of industrial emissions (Dorter, 2020; Lyu et al., 2016). VOCs from chemicals used in households are generally associated with 1,2-dichloropropene, 1,1dichloroethylene, acrylonitrile, 1,2-dibromoethane, 1,1,1-Trichloroethane, and benzyl chloride (Saeaw and Thepanondh, 2015). In addition, Freon 11, Freon 12, Freon 113, Freon 114, and carbon tetrachloride were the key tracers of ambient background concentrations (Li et al., 2016; Saeaw and Thepanondh, 2015; Li et al., 2016). The VOCs source profiles from the seven monitoring sites are presented in Figs. S5-S11. The potential emission sources of VOCs in the community area resolved by PMF were vehicle exhaust, non-PVC industrial processes, industrial processes (PVC), chemicals used in households, and background tracers. The possible emission sources at each location were also evaluated separately. For example, the possible emission sources at the HMTP can be explained as follows. There were five possible emission sources in the HMTP. Factor 1 was identified as vehicle emissions, and its contribution to the VOC mixing ratio was $36.91 \%$. Factor 2 was an industrial process source, and the contribution to the total VOC concentration of this source was $34.65 \%$. Factor 3 was identified as arising from industrial process (PVC) emissions, with a percentage contribution to the VOC mixing ratio of approximately 9.5. Factor 4 was the background concentration in ambient air, with a contribution to the total VOCs estimated to be $10.4 \%$. Factor 5 showed that emissions from chemicals used in households contributing approximately $8.5 \%$ to total VOCs. The overall results from the PMF analysis indicated that the VOC concentrations in ambient air in the community areas were mainly contributed by vehicle exhaust, accounting for 36.91$48.96 \%$ of the VOC mixing ratio followed by industrial processes (15.9-37.9\%). This could be explained by the fact that the monitoring stations were located near roads. This result was similar to the result of source analysis using the PMF model in other studies, which reported that vehicle emissions were the main source of VOCs in community areas (Hui et al., 2018; Shao et al., 2016; 
Zhang et al., 2017). In addition to the mobile source, emissions from industrial processes were also identified as the second largest contributor to VOC concentrations in the community area in this study.

\subsubsection{Within industrial area}

Within the industrial area, the PMF model calculated that there were eight factors grouped according to high correlation among compounds. However, these factors were categorized into three VOC emission sources. Sources of VOCs in the industrial area were identified using the marker VOCs of each source that had a high percent contribution to the same factors. In this study, the factors associated with a high percentage of 1,3-butadiene and benzene are markers of the petrochemical industry (Dumanoglu et al., 2014; Hui et al., 2018; Kalabokas et al., 2001). The results from the PMF analysis revealed a similar pattern of source contribution to the VOC mixing ratio as they were in the community area. Vehicle emissions were the major source of ambient VOCs, followed by industrial emissions. However, in the industrial area, the patterns of source contributions at each monitoring station differed. Because ambient VOCs were mainly emitted from non-stack sources, high VOCs could be observed in the vicinity of their sources (Saeaw and Thepanondh, 2015) and it was observed that a high concentration of tracer VOCs could be measured near their specific emission sources. For example, at stations I-4 and I-2, the concentrations of tracer VOCs representing the petrochemical industry were higher than at other stations because these stations were located close to the butadiene manufacturing factory. The possible contribution of each source to the measured VOC concentrations at each monitoring station in this study is summarized in Table 2.

Percentage of source contribution to measured VOCs concentration at each monitoring station under different seasons is summarized in Table S3. In the community area, the patterns of source contributions at each monitoring station in different temporal period (dry, wet season and annual) were not difference. VOC concentrations were mainly contributed by vehicle exhaust followed by industrial processes. However, within industrial area during the wet season PVC source is the dominant emission source for the station No. I-3 which results from high concentration of 1,2-dichloroethane (major raw material use in the PVC manufacturing) detected there. At I-2 station, during the wet season, petrochemical industry is identified as the largest emitter contributed to VOCs concentration due to high concentration of 1,3-butadiene which is a key signature of this source detected there. Percentage of source contribution to measured VOCs concentration at each monitoring station under different seasons is presented in supporting Information (Table S3).

Table 2. Percentage of source contribution to measured VOCs concentration at each monitoring station (\%).

\begin{tabular}{|c|c|c|c|c|c|c|}
\hline Station & $\begin{array}{l}\text { Mobile } \\
\text { source }\end{array}$ & $\begin{array}{l}\text { Industrial } \\
\text { process }\end{array}$ & $\begin{array}{l}\text { Industrial } \\
\text { process (PVC) }\end{array}$ & $\begin{array}{l}\text { Background } \\
\text { concentration }\end{array}$ & $\begin{array}{l}\text { Chemical used } \\
\text { in households }\end{array}$ & $\begin{array}{l}\text { Petrochemical } \\
\text { industry }\end{array}$ \\
\hline \multicolumn{7}{|c|}{ In the community area } \\
\hline HMTP & 36.9 & 34.6 & 9.5 & 10.4 & 8.5 & - \\
\hline BTKH & 41.5 & 29.6 & 3.6 & 20.2 & 5.1 & - \\
\hline WNFS & 48.9 & 21.9 & 8.6 & 13.1 & 7.4 & - \\
\hline MMTP & 47.8 & 16.3 & 14.7 & 14.4 & 6.8 & - \\
\hline MCLT & 45.4 & 15.9 & 10.7 & 19.9 & 7.9 & - \\
\hline BPLC & 38.7 & 37.9 & 13.7 & 5.3 & 4.5 & - \\
\hline NPKV & 43.3 & 33.5 & 5.6 & 12 & 5.6 & - \\
\hline \multicolumn{7}{|c|}{ Within industrial area } \\
\hline MIEO & - & 27.1 & 60.1 & - & - & 12.8 \\
\hline $\mathrm{I}-4$ & - & 38.5 & 6.0 & - & - & 55.5 \\
\hline I-3 & - & 43.3 & 41.6 & - & - & 15.1 \\
\hline E-IE & - & 61.3 & 7.3 & - & - & 31.5 \\
\hline I-2 & - & 28.8 & 7.5 & - & - & 63.7 \\
\hline I-7 & - & 58.1 & 13.2 & - & - & 28.7 \\
\hline $\mathrm{I}-1$ & - & 43.8 & 21.2 & - & - & 35 \\
\hline
\end{tabular}




\subsection{Interspecies Ratio Analysis}

In this study, the diagnostic ratios of benzene (B), toluene $(T)$, ethylbenzene (Ebz), and xylene (X) were used as indicators to investigate and estimate the relative contributions of vehicle and non-vehicle sources and the age of air mass of pollution in the atmosphere. BTEX was used because it is a major component of vehicle fuel. Therefore, using the BTEX ratio can better identify the source of VOCS, particularly when compared with analytical data from roadside areas.

The average T/B diagnostic ratios at the seven stations in the community area are shown in Fig. 2(a). These ratios were approximately 5.15, 4.38, 3.54, 4.37, 4.71, 4.76 and 3.59 at HMTP, BTKH, WNFS, MMTP, MCLT, BPLC and NPKV stations, respectively. The results suggest that vehicular emissions are an important source of VOCs in this study area. In addition, T/B values ranged from 3.54 to 5.15, indicative of fresh air mass at every station except at the HMTP station, revealing that the monitoring sites were affected by nearby emission sources (Kumar et al., 2018). This result was similar to that of a study in Orleans city, France ( $T / B=2.63-2.88$ ) (Jiang et al., 2017), in Doha, Qatar, with T/B in the range of 2.41-3.55 (Alfoidy et al., 2019), in Delhi (3.85.3) (Kumar et al., 2018), Doha (2.41-3.55) (Alfoidy et al., 2019), and Tehran (4.566) (Miri et al. 2016), which reported that mobile sources were the largest potential source of VOCs.

The average $\mathrm{X} / \mathrm{B}$ diagnostic ratios at the seven stations in the community area are presented in Fig. 2(b). The height ratio of X/B describes the fresh air mass, indicating that the sources of pollutants were close to the sampling station and the concentration was subject to a low impact from photochemical reactions (Niu et al., 2012; Singh et al., 2016). In this study, the average
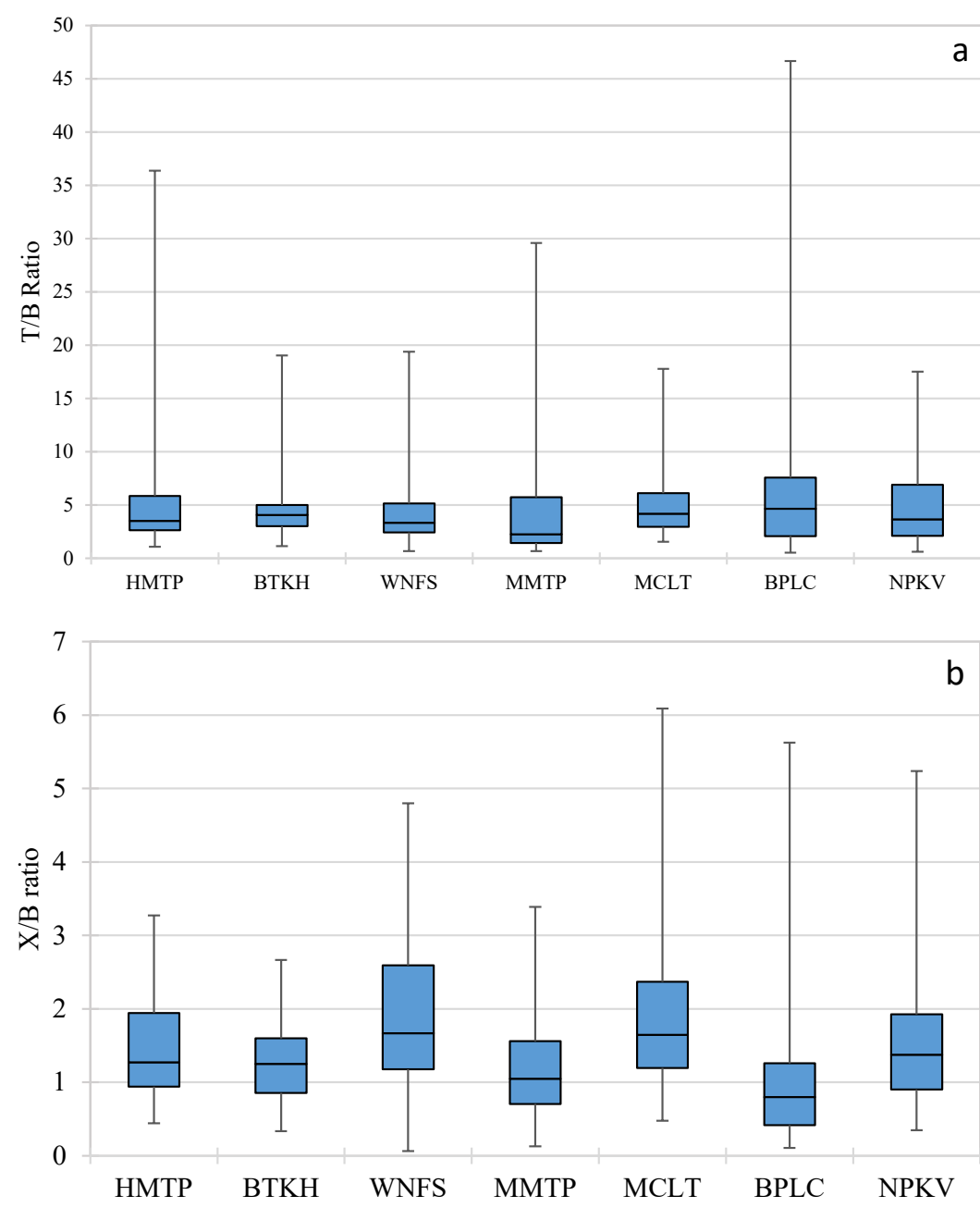

Fig. 2. (a) $T / B$ and (b) $X / B$ diagnostic ratios variability at seven stations in community area. The upper and lower bars show the max and min values. The upper and lower horizontal lines of the box indicate third and first quartile values. Horizontal lines inside the boxes show median value. 
values of $\mathrm{m}, \mathrm{p}-\mathrm{X} / \mathrm{B}, \mathrm{o}-\mathrm{X} / \mathrm{B}, \mathrm{Ebz} / \mathrm{B}$, and $\mathrm{m}, \mathrm{p}-\mathrm{X} / \mathrm{Ebz}$ were between $0.66-1.55,0.21-0.52,0.50-0.98$, and 1.33-2.27, respectively. These results confirmed that traffic emissions were the major contributor to VOC in the community area. A comparison of the calculated diagnostic ratios with other studies is summarized in Table 3.

Spearman's correlation coefficient analysis (two-tailed), was used to assess the correlation between the concentration of BTEX species at each monitoring location, as presented in Table 4. A moderate and strong correlation between ethylbenzene and xylene indicated that these VOCs might have been released from mobile emission sources. However, the low correlation between benzene and other BTEX compounds at BPLC and NPKV stations revealed contributions from other sources. However, BTEX compounds can be distributed in the industrial sector, especially in the petrochemical industry (Heibati et al., 2017). A weak correlation coefficient $(r<0.5)$ was found between some BTEX species in MMTP, BPLC, and NPKV stations, and a negative correlation between benzene and ethylbenzene was observed at BPLC station.

\subsection{Health Risk Assessment}

Arithmetic mean concentrations of VOCs measured in the community and industrial areas were used to evaluate the exposure and health risks to general populations and industrial

Table 3. The specific VOCs ratio (community area).

\begin{tabular}{|c|c|c|c|c|c|c|c|c|}
\hline Location & $\mathrm{T} / \mathrm{B}$ & $\mathrm{X} / \mathrm{B}$ & $m \cdot p-X / B$ & m.p-X/EB & $0-X / B$ & $\mathrm{~EB} / \mathrm{B}$ & Sampling location & Reference \\
\hline HMTP & 5.15 & - & 1.25 & 2.18 & 0.36 & 0.57 & urban area & This study, \\
\hline BTKH & 4.38 & - & 1.10 & 1.99 & 0.40 & 0.55 & urban area & Map Ta Phut, \\
\hline WNFS & 3.54 & - & 1.55 & 1.66 & 0.51 & 0.94 & urban area & Rayong, \\
\hline MMTP & 4.37 & - & 0.95 & 1.79 & 0.25 & 0.53 & urban area & Thailand \\
\hline MCLT & 4.71 & - & 1.46 & 1.49 & 0.52 & 0.98 & urban area & \\
\hline BPLC & 4.76 & - & 0.66 & 1.33 & 0.21 & 0.50 & urban area & \\
\hline NPKV & 3.59 & - & 1.40 & 2.27 & 0.32 & 0.62 & urban area & \\
\hline Tehran, Iran & $1.69-2.04$ & $1.77-3.91$ & - & - & - & $0.15-1.21$ & residential areas & $\begin{array}{l}\text { Baghani et al., } \\
2019\end{array}$ \\
\hline Shiraz, Iran & $2.02-3.07$ & - & $0.49-0.74$ & - & $0.62-0.89$ & $0.19-0.28$ & urban area & $\begin{array}{l}\text { Dehghani et } \\
\text { al., } 2018\end{array}$ \\
\hline Tehran, Iran & $2.63-2.88$ & $3.33-4.40$ & - & - & - & $2.13-2.80$ & residential areas & $\begin{array}{l}\text { Golkhorshidi } \\
\text { et al., } 2019\end{array}$ \\
\hline Orleans, France & $1.1-3.84$ & - & - & $1.9-2.5$ & - & - & semi-urban area & $\begin{array}{l}\text { Jiang et al., } \\
2017\end{array}$ \\
\hline Gorakhpur, India & 1.8 & 0.2 & - & 0.7 & - & - & urban area & $\begin{array}{l}\text { Masih et al., } \\
2016\end{array}$ \\
\hline Wuhan, China & 1.4 & - & - & - & - & - & urban area & $\begin{array}{l}\text { Hui et al., } \\
2018\end{array}$ \\
\hline Algiers, Algeria & $2.2-2.9$ & - & - & $2.4-5.3$ & - & - & road traffic sites & $\begin{array}{l}\text { Kerchich and } \\
\text { Kerbachi, } \\
2012\end{array}$ \\
\hline Hanoi, Vietnam & $1.1-1.4$ & - & - & $1.4-3.2$ & - & - & $\begin{array}{l}\text { heavy traffic urban } \\
\text { area }\end{array}$ & $\begin{array}{l}\text { Phuc and } \\
\text { Oanh, } 2018\end{array}$ \\
\hline $\begin{array}{l}\text { Northeastern } \\
\text { Brazil }\end{array}$ & $<2.7$ & - & $<1.8$ & - & $<0.9$ & - & urban area & $\begin{array}{l}\text { Cruz et al., } \\
2020\end{array}$ \\
\hline Ontario, Canada & $2.0-6.9$ & - & - & $2.6-3.7$ & - & - & $\begin{array}{l}\text { urban industrial } \\
\text { city }\end{array}$ & $\begin{array}{l}\text { Miller et al., } \\
2012\end{array}$ \\
\hline Tehran, Tran & $\begin{array}{l}2.307- \\
8.922\end{array}$ & - & $\begin{array}{l}0.887- \\
7.649\end{array}$ & $\begin{array}{l}0.63- \\
36.196\end{array}$ & - & - & urban area & $\begin{array}{l}\text { Miri et al., } \\
2019\end{array}$ \\
\hline NCT, India & $3.8-5.3$ & $0.7-2.8$ & - & - & - & - & urban and rural & $\begin{array}{l}\text { Kumar et al., } \\
2018\end{array}$ \\
\hline Doha, Qatar & $2.41-3.55$ & $0.84-5.03$ & - & $1.62-4.04$ & - & - & $\begin{array}{l}\text { urban, suburban } \\
\text { and rural }\end{array}$ & $\begin{array}{l}\text { Alfoldy et al., } \\
2019\end{array}$ \\
\hline
\end{tabular}


Table 4. Spearman's correlation coefficient $(r)$ between BTEX species at different sampling locations.

\begin{tabular}{|c|c|c|c|c|c|c|}
\hline Station & Pollutant & benzene & toluene & ethylbenzene & $\mathrm{m}, \mathrm{p}$-xylene & o-xylene \\
\hline \multirow[t]{5}{*}{ HMTP } & benzene & 1.000 & & & & \\
\hline & toluene & .600 & 1.000 & & & \\
\hline & ethylbenzene & .530 & .686 & 1.000 & & \\
\hline & m,p-xylene & .752 & .562 & .546 & 1.000 & \\
\hline & o-xylene & .706 & .817 & .752 & .764 & 1.000 \\
\hline \multirow[t]{5}{*}{ BTKH } & benzene & 1.000 & & & & \\
\hline & toluene & .701 & 1.000 & & & \\
\hline & ethylbenzene & .524 & .803 & 1.000 & & \\
\hline & m,p-xylene & .580 & .732 & .780 & 1.000 & \\
\hline & o-xylene & .598 & .808 & .827 & .904 & 1.000 \\
\hline \multirow[t]{5}{*}{ WNFS } & benzene & 1.000 & & & & \\
\hline & toluene & .815 & 1.000 & & & \\
\hline & ethylbenzene & .775 & .845 & 1.000 & & \\
\hline & m,p-xylene & .866 & .883 & .909 & 1.000 & \\
\hline & o-xylene & .774 & .828 & .852 & .913 & 1.000 \\
\hline \multirow[t]{5}{*}{ MMTP } & benzene & 1.000 & & & & \\
\hline & toluene & .815 & 1.000 & & & \\
\hline & ethylbenzene & .492 & .351 & 1.000 & & \\
\hline & m,p-xylene & .189 & .183 & .593 & 1.000 & \\
\hline & o-xylene & .457 & .409 & .741 & .723 & 1.000 \\
\hline \multirow[t]{5}{*}{ MCLT } & benzene & 1.000 & & & & \\
\hline & toluene & .813 & 1.000 & & & \\
\hline & ethylbenzene & .685 & .774 & 1.000 & & \\
\hline & m,p-xylene & .737 & .866 & .819 & 1.000 & \\
\hline & o-xylene & .759 & .861 & .818 & .928 & 1.000 \\
\hline \multirow[t]{5}{*}{ BPLC } & benzene & 1.000 & & & & \\
\hline & toluene & .117 & 1.000 & & & \\
\hline & ethylbenzene & -.037 & .774 & 1.000 & & \\
\hline & m,p-xylene & .084 & .734 & .735 & 1.000 & \\
\hline & o-xylene & .124 & .842 & .817 & .834 & 1.000 \\
\hline \multirow[t]{5}{*}{ NPKV } & benzene & 1.000 & & & & \\
\hline & toluene & .361 & 1.000 & & & \\
\hline & ethylbenzene & .269 & .779 & 1.000 & & \\
\hline & m,p-xylene & .585 & .613 & .574 & 1.000 & \\
\hline & o-xylene & .399 & .847 & .829 & .574 & 1.000 \\
\hline
\end{tabular}

correlation is significant at the 0.01 level (2-tailed).

Correlations $(r>0.7)$ are presented in bold letters.

workers. The risk level was classified into four groups. High carcinogenic risk was defined as risk $>1 \times 10^{-4}$, probable risk = $1 \times 10^{-5}-10^{-4}$, possible risk $=1 \times 10^{-6}-1 \times 10^{-5}$, and risk less than $1 \times$ $10^{-6}$ as negligible risk (Kumar et al., 2018; Tohid et al., 2019).

\subsubsection{Non-carcinogenic risk}

Table 5 presents the cumulative non-cancer risk obtained from the calculation of the hazard quotient (HQ) of VOCs affecting each target organ system at each receptor station. Overall results in the community area indicated that the highest $\mathrm{HQ}$ was obtained from 1.3 butadiene, 1,1,2 trichloroethane and 3-chloropropene. Summation of $\mathrm{HQ}$ for the same target organ (HI) was within the safety level $(\mathrm{HI}<1)$, indicating low non-carcinogenic risk from VOCs in the general population living in the community area.

For the industrial area, the highest $\mathrm{HQ}$ was computed from acrolein (in the range $1.13 \times 10^{\circ}-$ $\left.5.75 \times 10^{\circ}\right)$. The hazard index $(\mathrm{HI})$ for the respiratory, reproductive, and nervous systems exceeded 1.0 , indicating a high non-carcinogenic risk to workers. These results clearly indicate the necessity 
Table 5. Cumulative hazard index $(\mathrm{HI})$ of non-carcinogen chronic health impact on each target organ system.

\begin{tabular}{|c|c|c|c|c|c|c|c|c|c|c|c|}
\hline \multirow[b]{2}{*}{$\begin{array}{l}\text { Monitoring - } \\
\text { stations }\end{array}$} & \multicolumn{11}{|c|}{ Target organ systems } \\
\hline & $\begin{array}{l}\text { Respiratory } \\
\text { System }\end{array}$ & $\begin{array}{l}\text { Hematologic } \\
\text { System }\end{array}$ & $\begin{array}{l}\text { Nervous } \\
\text { System }\end{array}$ & $\begin{array}{l}\text { Cardiovascular } \\
\text { System }\end{array}$ & $\begin{array}{l}\text { Reproductive } \\
\text { System }\end{array}$ & Development & $\begin{array}{l}\text { Alimentary } \\
\text { System }\end{array}$ & Kidney & $\begin{array}{l}\text { Endocrine } \\
\text { System }\end{array}$ & Urinary & Eye \\
\hline \multicolumn{12}{|c|}{ Community area } \\
\hline HMTP & $5.68 \mathrm{E}-01$ & $1.14 \mathrm{E}-01$ & 4.41E-01 & 2.75E-02 & 3.99E-01 & 7.04E-02 & 4.78E-02 & $3.45 \mathrm{E}-02$ & $2.74 \mathrm{E}-02$ & 1.59E-01 & $1.39 \mathrm{E}-01$ \\
\hline BTKH & 7.23E-01 & $1.06 \mathrm{E}-01$ & 2.93E-01 & 2.91E-02 & 3.71E-01 & $4.81 \mathrm{E}-02$ & 4.30E-02 & 3.70E-02 & $2.89 \mathrm{E}-02$ & $1.43 \mathrm{E}-01$ & $1.45 \mathrm{E}-01$ \\
\hline WNFS & $5.74 \mathrm{E}-01$ & $7.88 \mathrm{E}-02$ & $6.50 \mathrm{E}-01$ & 2.79E-02 & $1.58 \mathrm{E}-01$ & $5.14 \mathrm{E}-02$ & $4.12 \mathrm{E}-02$ & $3.65 \mathrm{E}-02$ & $2.83 \mathrm{E}-02$ & $1.40 \mathrm{E}-01$ & $1.14 \mathrm{E}-01$ \\
\hline MMTP & $5.73 \mathrm{E}-01$ & $1.23 \mathrm{E}-01$ & $5.58 \mathrm{E}-01$ & 3.34E-02 & 4.95E-01 & 8.57E-02 & $5.96 \mathrm{E}-02$ & 4.15E-02 & 3.30E-02 & $1.45 \mathrm{E}-01$ & $1.48 \mathrm{E}-01$ \\
\hline MCLT & $6.35 \mathrm{E}-01$ & 7.06E-02 & 3.04E-01 & $2.78 \mathrm{E}-02$ & $1.08 \mathrm{E}-01$ & $4.58 \mathrm{E}-02$ & $4.12 \mathrm{E}-02$ & $3.51 E-02$ & $2.75 \mathrm{E}-02$ & $1.39 \mathrm{E}-01$ & $1.50 \mathrm{E}-01$ \\
\hline BPLC & $5.78 \mathrm{E}-01$ & 1.99E-01 & $3.78 \mathrm{E}-01$ & $2.88 \mathrm{E}-02$ & $1.76 \mathrm{E}-01$ & $5.46 \mathrm{E}-02$ & $4.62 \mathrm{E}-02$ & $3.63 E-02$ & $2.95 \mathrm{E}-02$ & $1.47 \mathrm{E}-01$ & $1.53 \mathrm{E}-01$ \\
\hline NPKV & 5.07E-01 & $1.20 \mathrm{E}-01$ & 4.29E-01 & 3.71E-02 & 9.27E-02 & 4.89E-02 & $5.04 \mathrm{E}-02$ & $3.68 \mathrm{E}-02$ & $2.99 \mathrm{E}-02$ & $1.41 \mathrm{E}-01$ & $2.68 \mathrm{E}-01$ \\
\hline \multicolumn{12}{|c|}{ Industrial area } \\
\hline MIEO & $3.13 E+00$ & $1.72 \mathrm{E}-02$ & $1.02 \mathrm{E}+00$ & 3.06E-03 & 2.00E-01 & 1.07E-02 & $1.76 \mathrm{E}-02$ & 7.03E-03 & - & - & 2.57E-02 \\
\hline $\mathrm{I}-4$ & $3.68 \mathrm{E}+00$ & 7.60E-02 & $8.20 \mathrm{E}-02$ & $2.92 \mathrm{E}-03$ & $1.08 \mathrm{E}+00$ & $9.10 \mathrm{E}-03$ & $9.28 \mathrm{E}-03$ & $5.26 \mathrm{E}-03$ & - & - & $3.08 \mathrm{E}-02$ \\
\hline $1-3$ & $3.80 E+00$ & 2.87E-02 & $5.94 \mathrm{E}-01$ & $2.98 \mathrm{E}-03$ & 2.38E-01 & $1.08 \mathrm{E}-02$ & $4.28 \mathrm{E}-02$ & $6.89 \mathrm{E}-03$ & - & - & $1.01 \mathrm{E}-01$ \\
\hline E-IE & $3.00 \mathrm{E}+00$ & $2.25 \mathrm{E}-02$ & 4.60E-02 & 2.89E-03 & $1.83 \mathrm{E}-01$ & $1.03 \mathrm{E}-02$ & 8.02E-03 & $6.53 \mathrm{E}-03$ & - & - & 2.57E-02 \\
\hline I-2 & $6.29 E+00$ & 3.93E-02 & $6.73 \mathrm{E}-02$ & 2.89E-03 & $2.52 E+00$ & 3.29E-02 & $2.67 \mathrm{E}-02$ & 2.33E-02 & - & - & 2.57E-02 \\
\hline $1-7$ & $1.18 \mathrm{E}+01$ & $2.25 \mathrm{E}-02$ & $6.82 \mathrm{E}-02$ & $2.98 \mathrm{E}-03$ & 3.56E-01 & $9.48 \mathrm{E}-03$ & $7.16 \mathrm{E}-03$ & $5.13 E-03$ & - & - & 4.84E-02 \\
\hline I-1 & $3.01 E+00$ & $1.55 \mathrm{E}-02$ & $6.55 \mathrm{E}-02$ & 3.53E-03 & $4.86 \mathrm{E}-02$ & $9.00 \mathrm{E}-03$ & 8.73E-03 & $5.36 \mathrm{E}-03$ & - & - & $2.57 \mathrm{E}-02$ \\
\hline
\end{tabular}

of industrial employees to use personal protective equipment during their work in industrial process areas.

\subsubsection{Carcinogenic risk}

The carcinogenic risk was analyzed for 20 and 16 carcinogens found in the community and industrial areas, respectively. In this study, the acceptable level for carcinogenic chronic risk was set at $1 \times 10^{-6}$.

1,2 dibromoethane had the highest cancer risk in the community. Other compounds were also associated with carcinogenic risks higher than the acceptable level (1,2-dichloroethane, benzene, 1,3-butadiene, acrylonitrile, hexachloro-1,3-butadiene, 1,1,2,2-tetrachloroethane, ethylbenzene, chloromethane, chloroform, carbon tetrachloride, benzyl chloride, and 1,4-dichlorobenzene) at every monitoring station. Vinyl chlorides were greater than $1 \times 10^{-6}$ at MMTP and BPLC stations, while 3-chloropropene and trichloroethylene exceeded the threshold of $1 \times 10^{-6}$ at WNFS and NPKV stations. This result revealed the threat to human health from inhalation of carcinogens to people living in the vicinity of this industrial complex.

Data within the industrial area indicated carcinogenic risk at every station arising from inhalation of 1,2-dichloroethane, 1,2-dibromoethane, 1,3-butadiene, benzene, benzyl chloride, 1,1,2,2-tetrachloroethane, acrylonitrile, acetaldehyde, chloroform, and 1,4-dichlorobenzene ( $>1$ $\left.\times 10^{-6}\right)$. The carcinogenic risks of hazardous VOCs in the community and industrial areas are presented in Figs. 3(a) and 3(b).

\section{CONCLUSIONS}

Intensive measurements of airborne VOCs were conducted in the largest petroleum/petrochemical industrial complex in Thailand. The contribution and potential health impact of VOCs monitored at 14 monitoring stations located within and outside of the industrial estate were evaluated, and likely sources investigated. In the community area, aromatic hydrocarbons contributed the most to the total concentration of VOCs, followed by halogenated hydrocarbons and alkenes, respectively. Toluene, which was mainly emitted from mobile sources, was the most abundant VOC. As for the industrial area, alkene was the largest contributor to the total VOC concentration measured within the industrial complex, followed by aromatic and halogenated hydrocarbons. PMF results showed that the signature of the vehicle emissions, industrial processes, and petrochemical profile mostly contributed to VOC concentrations. The calculation of $\mathrm{HQ}$ and $\mathrm{HI}$ indicated the probability of potential non-carcinogenic risk from inhalation in both the industrial area and its nearby community. The inhalation unit risk was also applied to evaluate potential cancer risk. Analytical results in community and industrial areas revealed that there were some VOCs with 

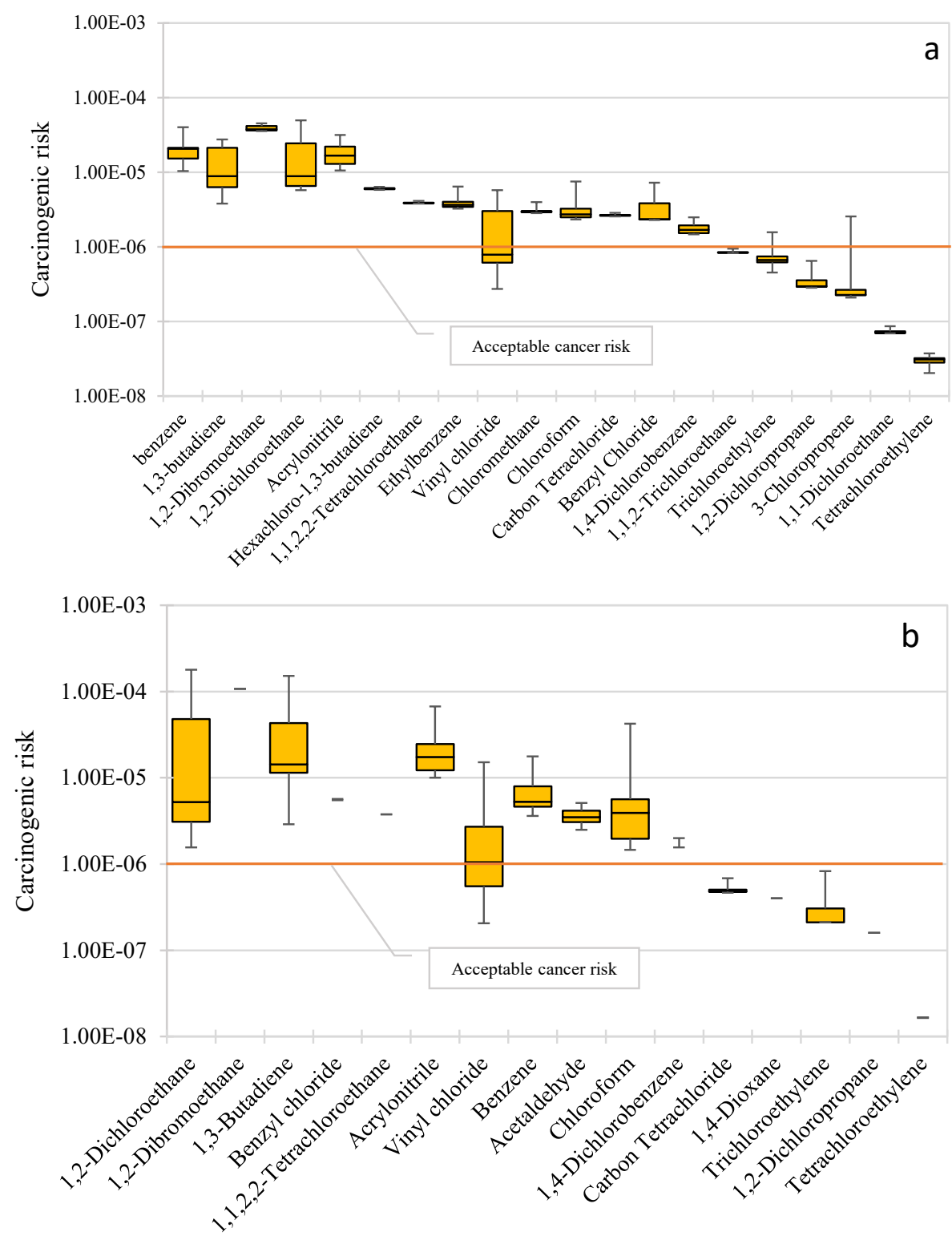

Fig. 3. Percentile distribution $\left(25^{\text {th }}-75^{\text {th }}\right)$ of individual VOCs in (a) community and (b) industrial area. The upper and lower bars show the max and min values. The lower and upper horizontal lines of the box indicate first and third quartile values. Horizontal lines inside the boxes show median values.

values exceeding the acceptable risk level of $1 \times 10^{-6}$. The findings of this research clearly indicate the potential health impact of inhalation to VOCs in this study area. The methodology presented in this study demonstrates the necessity of identifying the actual emission sources and their contributions to ambient air pollution to set up appropriate emission controls and mitigation measures for the effective management of industrial air pollution.

\section{ACKNOWLEDGMENTS}

The authors would like to thank the Pollution Control Department (PCD) and the Industrial Estate Authority of Thailand (IEAT) in providing VOCs monitoring data for this work. Financial support from the Thailand Research Fund through the Royal Golden Jubilee Ph.D. Program (Grant No. PHD/0066/2558) to Nattaporn Pinthong and Sarawut Thepanondh is acknowledged. This study was supported for publication by Faculty of Public Health, Mahidol University, Thailand. 


\section{SUPPLEMENTARY MATERIAL}

Supplementary material for this article can be found in the online version at https://doi. org/10.4209/aaqr.210064

\section{REFERENCES}

Agency for Toxic Substances and Disease Registry (ATSDR) (2020). Toxicological Profiles. https://www.atsdr.cdc.gov/toxprofiledocs/index.html/ (accessed 30 November 2020).

Alfoldy, B., Mahfouz, M.M.K., Yigiterhan, O., Safi, M.A., Elnaiem, A.E., Giamberini, S. (2019). BTEX, nitrogen oxides, ammonia and ozone concentrations at traffic influenced and background urban sites in an arid environment. Atmos. Pollut. Res. 10, 445-454. https://doi.org/10.1016/j. apr.2018.08.009

Baghani, A.N., Sorooshian, A., Heydari, M., Sheikhi, R., Golbaz, S., Ashournejad, Q., Kermani, M., Golkhorshidi, F., Barkhordari, A., Jafari, A.J., Delikhoon, M., Shahsavani, A. (2019). A case study of BTEX characteristics and health effects by major point sources of pollution during winter in Iran. Environ. Pollut. 247, 607-617. https://doi.org/10.1016/j.envpol.2019.01.070

Bari, M.A., Kindzierski, W.B. (2018). Ambient volatile organic compounds (VOCs) in Calgary, Alberta: Sources and screening health risk assessment. Sci. Total Environ. 631-632, 627-640. https://doi.org/10.1016/j.scitotenv.2018.03.023

Bozkurt, Z., Üzmez, Ö.Ö., Döğeroğlu, T., Artun, G., Gaga, E.O. (2018). Atmospheric concentrations of $\mathrm{SO}_{2}, \mathrm{NO}_{2}$, ozone and VOCs in Düzce, Turkey using passive air samplers: Sources, spatial and seasonal variations, and health risk estimation. Atmos. Pollut. Res. 9, 1146-1156. https://doi.org/10.1016/j.apr.2018.05.001

Carter, W.P.L. (1994). Development of ozone reactivity scales for volatile organic compounds. J. Air Waste Manage. Assoc. 44, 881-899. https://doi.org/10.1080/1073161X.1994.10467290

Caselli, M., de Gennaro, G., Marzocca, A., Trizio, L., Tutino, M. (2010). Assessment of the impact of the vehicular traffic on BTEX concentration in ring roads in urban areas of Bari (Italy). Chemosphere 81, 306-311. https://doi.org/10.1016/j.chemosphere.2010.07.033

Chen, C.H., Chuang, Y.C., Hsieh, C.C., Lee, C.S. (2019). VOC characteristics and source apportionment at a PAMS site near an industrial complex in central Taiwan. Atmos. Pollut. Res. 10, 1060-1074. https://doi.org/10.1016/j.apr.2019.01.014

Cruz, L.P.S., Santos, D.F., dos Santos, I.F., Gomes, Í.V.S., Santos, A.V.S., Souza, K.S.P.P. (2020). Exploratory analysis of the atmospheric levels of BTEX, criteria air pollutants and meteorological parameters in a tropical urban area in Northeastern Brazil. Microchem. J. 152, 104265. https://doi.org/10.1016/j.microc.2019.104265

Dorter, M., Odabasi, M., Yenisoy-Karakas, S. (2020). Source apportionment of biogenic and anthropogenic VOCs in Bolu plateau. Sci. Total Environ. 731, 139201. https://doi.org/10.1016/ j.scitotenv.2020.139201

Du, Z., Mo, J., Zhang, Y. (2014). Risk assessment of population inhalation exposure to volatile organic compounds and carbonyls in urban China. Environ. Int. 73, 33-45. https://doi.org/10.1 016/j.envint.2014.06.014

Dumanoglu, Y., Kara, M., Altiok, H., Odabasi, M., Elbir, T., Bayram, A. (2014). Spatial and seasonal variation and source apportionment of volatile organic compounds (VOCs) in a heavily industrialized region. Atmos. Environ. 98, 168-178. https://doi.org/10.1016/j.atmosenv.2014. 08.048

Duodu, G.O., Ogogo, K.N., Mummullage, S., Harden, F., Goonetilleke, A., Ayoko, G.A. (2017). Source apportionment and risk assessment of PAHs in Brisbane River sediment, Australia. Ecol. Indic. 73, 784-799. https://doi.org/10.1016/j.ecolind.2016.10.038

Fu, S., Guo, M., Luo, J., Han, D., Chen, X., Jia, H., Jin, X., Liao, H., Wang, X., Fan, L., Cheng, J. (2020). Improving VOCs control strategies based on source characteristics and chemical reactivity in a typical coastal city of South China through measurement and emission inventory. Sci. Total Environ. 744, 140825. https://doi.org/10.1016/j.scitotenv.2020.140825

Golkhorshidi, F., Sorooshian, A., Jafari, A.J., Baghani, A.N., Kermani, M., Kalantary, R.R., Ashournejad, Q., Delikhoon, M. (2019). On the nature and health impacts of BTEX in a populated 
middle eastern city: Tehran, Iran. Atmos. Pollut. Res. 10, 921-930. https://doi.org/10.1016/j.a pr.2018.12.020

Guo, H., Cheng, H.R., Ling, Z.H., Louie, P.K., Ayoko, G.A. (2011). Which emission sources are responsible for the volatile organic compounds in the atmosphere of Pearl River Delta? J. Hazard. Mater. 188, 116-124. https://doi.org/10.1016/j.jhazmat.2011.01.081

Hanma, P., Thepanondh, S., Chompunth, C., Kwonpongsagoon, S., Panya, L., Sukjit, N. (2021). Extent and magnitude of industrial stack emissions on ambient particulate concentrations. Int. J. Geomate. 21, 202-209. https://doi.org/10.21660/2021.84.j2189

Hopke, P.K. (2016). Review of receptor modeling methods for source apportionment. J. Air Waste Manage. Assoc. 66, 237-259. https://doi.org/10.1080/10962247.2016.1140693

Huang, X., Zhang, Y., Yang, W., Huang, Z., Wang, Y., Zhang, Z., He, Q., Lü, S., Huang, Z., Bi, X., Wang, X. (2017). Effect of traffic restriction on reducing ambient volatile organic compounds (VOCs): Observation-based evaluation during a traffic restriction drill in Guangzhou, China. Atmos. Environ. 161, 61-70. https://doi.org/10.1016/j.atmosenv.2017.04.035

Huang, Y., Ling, Z.H., Lee, S.C., Ho, S.S.H., Cao, J.J., Blake, D.R., Cheng, Y., Lai, S.C., Ho, K.F., Gao, Y., Cui, L., Louie, P.K.K. (2015). Characterization of volatile organic compounds at a roadside environment in Hong Kong: An investigation of influences after air pollution control strategies. Atmos. Environ. 122, 809-818. https://doi.org/10.1016/j.atmosenv.2015.09.036

Huang, Y.S., Hsieh, C.C. (2019). Ambient volatile organic compound presence in the highly urbanized city: source apportionment and emission position. Atmos. Environ. 206, 45-59. https://doi.org/10.1016/j.atmosenv.2019.02.046

Huang, Y.S., Hsieh, C.C. (2020). VOC characteristics and sources at nine photochemical assessment monitoring stations in western Taiwan. Atmos. Environ. 240, 117741. https://doi.org/10.1016/j.atmosenv.2020.117741

Hui, L., Liu, X., Tan, Q., Feng, M., An, J., Qu, Y., Zhang, Y., Jiang, M. (2018). Characteristics, source apportionment and contribution of VOCs to ozone formation in Wuhan, Central China. Atmos. Environ. 192, 55-71. https://doi.org/10.1016/j.atmosenv.2018.08.042

Hui, L., Liu, X., Tan, Q., Feng, M., An, J., Qu, Y., Zhang, Y., Cheng, N. (2019). VOC characteristics, sources and contributions to SOA formation during haze events in Wuhan, Central China. Sci. Total Environ. 650, 2624-2639. https://doi.org/10.1016/j.scitotenv.2018.10.029

Hui, L., Liu, X., Tan, Q., Feng, M., An, J., Qu, Y., Zhang, Y., Deng, Y., Zhai, R., Wang, Z. (2020). VOC characteristics, chemical reactivity and sources in urban Wuhan, central China. Atmos. Environ. 224, 117340. https://doi.org/10.1016/j.atmosenv.2020.117340

International Agency for Research on Cancer (IARC) (2020). Agents Classified by the IARC Monographs, Volumes 1-128. https://monographs.iarc.fr/agents-classified-by-the-iarc/ (accessed 20 January 2020).

Jain, S., Sharma, S.K., Mandal, T.K., Saxena, M. (2018). Source apportionment of PM10 in Delhi, India using PCA/APCS, UNMIX and PMF. Particuology 37, 107-118. https://doi.org/10.1016/j.p artic.2017.05.009

Jiang, X.Q., Mei, X.D., Feng, D. (2016). Air pollution and chronic airway diseases: What should people know and do? J. Thorac. Dis. 8, E31-E40. https://doi.org/10.3978/j.issn.2072-1439.2015.11.50

Jiang, Z., Grosselin, B., Daele, V., Mellouki, A., Mu, Y. (2017). Seasonal and diurnal variations of BTEX compounds in the semi-urban environment of Orleans, France. Sci. Total Environ. 574, 1659-1664. https://doi.org/10.1016/j.scitotenv.2016.08.214

Jindamanee, K., Thepanondh, S., Aggapongpisit, N., Suktawee, S. (2020). Source apportionment analysis of volatile organic compounds using positive matrix factorization coupled with conditional bivariate probability function in the industrial areas. EnvironmentAsia 13, 31-49. https://doi.org/10.14456/ea.2020.28

Kalabokas, P.D., Hatzianestis, J., Bartzis, J.G., Papagiannakopoulos, P. (2001). Atmospheric concentrations of saturated and aromatic hydrocarbons around a Greek oil refinery. Atmos. Environ. 35, 2545-2555. https://doi.org/10.1016/S1352-2310(00)00423-4

Kim, S., Kim, T.Y., Yi, S.M., Heo, J. (2018). Source apportionment of $\mathrm{PM}_{2.5}$ using positive matrix factorization (PMF) at a rural site in Korea. J. Environ. Manage. 214, 325-334. https://doi.org/ 10.1016/j.jenvman.2018.03.027

Kumar, A., Singh, D., Kumar, K., Singh, B.B., Jain, V.K. (2018). Distribution of VOCs in urban and rural atmospheres of subtropical India: Temporal variation, source attribution, ratios, OFP and 
risk assessment. Sci. Total Environ. 613-614, 492-501. https://doi.org/10.1016/j.scitotenv.20 17.09.096

Leuchner, M., Rappenglück, B. (2010). VOC source-receptor relationships in Houston during TexAQS-II. Atmos. Environ. 44, 4056-4067. https://doi.org/10.1016/j.atmosenv.2009.02.029

Li, B., Ho, S.S.H., Qu, L., Gong, S., Ho, K.F., Zhao, D., Qi, Y., Chan, C.S. (2021). Temporal and spatial discrepancies of VOCs in an industrial-dominant city in China during summertime. Chemosphere 264, 128536. https://doi.org/10.1016/j.chemosphere.2020.128536

Li, J., Wu, R., Li, Y., Hao, Y., Xie, S., Zeng, L. (2016). Effects of rigorous emission controls on reducing ambient volatile organic compounds in Beijing, China. Sci. Total Environ. 557-558, 531-541. https://doi.org/10.1016/j.scitotenv.2016.03.140

Li, J., Zhai, C., Yu, J., Liu, R., Li, Y., Zeng, L., Xie, S. (2018). Spatiotemporal variations of ambient volatile organic compounds and their sources in Chongqing, a mountainous megacity in China. Sci. Total Environ. 627, 1442-1452. https://doi.org/10.1016/j.scitotenv.2018.02.010

Li, Q., Su, G., Li, C., Liu, P., Zhao, X., Zhang, C., Sun, X., Mu, Y., Wu, M., Wang, Q., Sun, B. (2020). An investigation into the role of VOCs in SOA and ozone production in Beijing, China. Sci. Total Environ. 720, 137536. https://doi.org/10.1016/j.scitotenv.2020.137536

Li, Y., Yin, S., Yu, S., Yuan, M., Dong, Z., Zhang, D., Yang, L., Zhang, R. (2020). Characteristics, source apportionment and health risks of ambient VOCs during high ozone period at an urban site in central plain, China. Chemosphere 250, 126283. https://doi.org/10.1016/j.chemosphere.2020. 126283

Ling, Z.H., Guo, H., Cheng, H.R., Yu, Y.F. (2011). Sources of ambient volatile organic compounds and their contributions to photochemical ozone formation at a site in the Pearl River Delta, southern China. Environ. Pollut. 159, 2310-2319. https://doi.org/10.1016/j.envpol.2011.05.001

Ling, Z.H., Guo, H. (2014). Contribution of VOC sources to photochemical ozone formation and its control policy implication in Hong Kong. Environ. Sci. Policy 38, 180-191. https://doi.org/10. 1016/j.envsci.2013.12.004

Liu, P.W., Yao, Y.C., Tsai, J.H., Hsu, Y.C., Chang, L.P., Chang, K.H. (2008). Source impacts by volatile organic compounds in an industrial city of southern Taiwan. Sci. Total Environ. 398, 154-163. https://doi.org/10.1016/j.scitotenv.2008.02.053

Liu, Y., Song, M., Liu, X., Zhang, Y., Hui, L., Kong, L., Zhang, Y., Zhang, C., Qu, Y., An, J., Ma, D., Tan, Q., Feng, M. (2020). Characterization and sources of volatile organic compounds (VOCs) and their related changes during ozone pollution days in 2016 in Beijing, China. Environ. Pollut. 257, 113599. https://doi.org/10.1016/j.envpol.2019.113599

Liu, Y., Kong, L., Liu, X., Zhang, Y., Li, C., Zhang, Y., Zhang, C., Qu, Y., An, J., Ma, D., Tan, Q., Feng, M., Zha, S. (2021). Characteristics, secondary transformation, and health risk assessment of ambient volatile organic compounds (VOCs) in urban Beijing, 12, 33-46 China. Atmos. Pollut. Res. https://doi.org/10.1016/j.apr.2021.01.013

Lyu, X.P., Chen, N., Guo, H., Zhang, W.H., Wang, N., Wang, Y., Liu, M. (2016). Ambient volatile organic compounds and their effect on ozone production in Wuhan, central China. Sci. Total Environ. 541, 200-209. https://doi.org/10.1016/j.scitotenv.2015.09.093

Masih, A., Lall, A.S., Taneja, A., Singhvi, R. (2016). Inhalation exposure and related health risks of BTEX in ambient air at different microenvironments of a terai zone in north India. Atmos. Environ. 147, 55-66. https://doi.org/10.1016/j.atmosenv.2016.09.067

McCarthy, M.C., Aklilu, Y.A., Brown, S.G., Lyder, D.A. (2013). Source apportionment of volatile organic compounds measured in Edmonton, Alberta. Atmos. Environ. 81, 504-516. https://doi.org/10.1016/j.atmosenv.2013.09.016

Miller, L., Xu, X., Grgicak-Mannion, A., Brook, J., Wheeler, A. (2012). Multi-season, multi-year concentrations and correlations amongst the BTEX group of VOCs in an urbanized industrial city. Atmos. Environ. 61, 305-315. https://doi.org/10.1016/j.atmosenv.2012.07.041

Miri, M., Rostami Aghdam Shendi, M., Ghaffari, H.R., Ebrahimi Aval, H., Ahmadi, E., Taban, E., Gholizadeh, A., Yazdani Aval, M., Mohammadi, A., Azari, A. (2016). Investigation of outdoor BTEX: Concentration, variations, sources, spatial distribution, and risk assessment. Chemosphere 163, 601-609. https://doi.org/10.1016/j.chemosphere.2016.07.088

Mozaffar, A., Zhang, Y.L., Fan, M., Cao, F., Lin, Y.C. (2020). Characteristics of summertime ambient VOCs and their contributions to $\mathrm{O}_{3}$ and SOA formation in a suburban area of Nanjing, China. Atmos. Res. 240, 104923. https://doi.org/10.1016/j.atmosres.2020.104923 
Niu, Z., Zhang, H., Xu, Y., Liao, X., Xu, L., Chen, J. (2012). Pollution characteristics of volatile organic compounds in the atmosphere of Haicang District in Xiamen City, Southeast China. J. Environ. Monit. 14, 1145-1152. https://doi.org/10.1039/c2em10884d

Paatero, P., Tapper, U. (1993). Analysis of different modes of factor analysis as least squares fit problems. Chemomet. Intell. Lab. Syst. 18, 183-94. https://doi.org/10.1016/0169-7439(93)80 055-M

Paatero, P., Tapper, U. (1994). Positive matrix factorization-a nonnegative factor model with optimal utilization of error-estimates of data values. Environmetrics 5, 111-126. https://doi.org/10.1002/env.3170050203

Phuc, N.H., Kim Oanh, N.T. (2018). Determining factors for levels of volatile organic compounds measured in different microenvironments of a heavy traffic urban area. Sci. Total Environ. 627, 290-303. https://doi.org/10.1016/j.scitotenv.2018.01.216

Pollution Control Department (PCD) (2018). Thailand State of Pollution Report 2018. https://www.pcd.go.th/publication/3657/ (accessed 20 October 2019).

Qiu, W., Li, S., Liu, Y., Lu, K. (2019). Petrochemical and industrial sources of volatile organic compounds analyzed via regional wind-driven network in Shanghai. Atmosphere 10, 760. https://doi.org/10.3390/atmos10120760

Rodricks, J.V., Brett, S.M., Wrenn, G.C. (1987). Significant risk decisions in federal regulatory agencies. Regul. Toxicol. Pharm. 7, 307-320. https://doi.org/10.1016/0273-2300(87)90038-9

Saeaw, N., Thepanondh, S. (2015). Source apportionment analysis of airborne VOCs using positive matrix factorization in industrial and urban areas in Thailand. Atmos. Pollut. Res. 6, 644-650. https://doi.org/10.5094/APR.2015.073

Saikomo, S., Thepanondh, S., Laowagul, W. (2019). Emission losses and dispersion of volatile organic compounds from tank farm of petroleum refinery complex. J. Environ. Health Sci. Eng. 17, 561-570. https://doi.org/10.1007/s40201-019-00370-1

Shao, P., An, J., Xin, J., Wu, F., Wang, J., Ji, D., Wang, Y. (2016). Source apportionment of VOCs and the contribution to photochemical ozone formation during summer in the typical industrial area in the Yangtze River Delta, China. Atmos. Res. 176-177, 64-74. https://doi.org/10.1016/j. atmosres.2016.02.015

Singh, D., Kumar, A., Kumar, K., Singh, B., Mina, U., Singh, B.B., Jain, V.K. (2016). Statistica modeling of $\mathrm{O}_{3}, \mathrm{NO}_{\mathrm{x}}, \mathrm{CO}, \mathrm{PM}_{2.5}$, VOCs and noise levels in commercial complex and associated health risk assessment in an academic institution. Sci. Total Environ. 572, 586-594. https://doi.org/10.1016/j.scitotenv.2016.08.086

Song, C., Liu, B., Dai, Q., Li, H., Mao, H. (2019). Temperature dependence and source apportionment of volatile organic compounds (VOCs) at an urban site on the north China plain. Atmos. Environ. 207, 167-181. https://doi.org/10.1016/j.atmosenv.2019.03.030

Song, S.K., Shon, Z.H., Kang, Y.H., Kim, K.H., Han, S.B., Kang, M., Bang, J.H., Oh, I. (2019). Source apportionment of VOCs and their impact on air quality and health in the megacity of Seoul. Environ. Pollut. 247, 763-774. https://doi.org/10.1016/j.envpol.2019.01.102

Tan, Q., Zhou, L., Liu, H., Feng, M., Qiu, Y., Yang, F., Jiang, W., Wei, F. (2020). Observation-based summer $\mathrm{O}_{3}$ control effect evaluation: A case study in Chengdu, a megacity in Sichuan Basin, China. Atmosphere 11, 1278; https://doi.org/10.3390/atmos11121278

Thepanondh, S., Varoonphan, J., Sarutichart, P., Makkasap, T. (2011). Airborne volatile organic compounds and their potential health impact on the vicinity of petrochemical industrial complex. Water Air Soil Pollut. 214, 83-92. https://doi.org/10.1007/s11270-010-0406-0

Tiwari, V., Hanai, Y., Masunaga, S. (2010). Ambient levels of volatile organic compounds in the vicinity of petrochemical industrial area of Yokohama, Japan. Air Qual. Atmos. Health 3, 6575. https://doi.org/10.1007/s11869-009-0052-0

Tohid, L., Sabeti, Z., Sarbakhsh, P., Zoroufchi Benis, K., Shakerkhatibi, M., Rasoulzadeh, Y., Rahimian, R., Darvishali, S. (2019). Spatiotemporal variation, ozone formation potential and health risk assessment of ambient air VOCs in an industrialized city in Iran. Atmos. Pollut. Res. 10, 556-563. https://doi.org/10.1016/j.apr.2018.10.007

United States Environmental Protection Agency (U.S. EPA) (2009). Risk Assessment Guidance for Superfund (RAGS). In: Volume I Human Health Evaluation Manual (Part F, Supplemental Guidance for Inhalation Risk Assessment). Washington, DC. EPA-540-R070-002, OSWER 9285.7-82. 
United States Environmental Protection Agency (U.S. EPA) (2014). EPA Positive Matrix Factorization (PMF) 5.0 Fundamentals and User Guide. Washington, DC. EPA/600/R-14/108.

United States Environmental Protection Agency (U.S. EPA) (2017a). IRIS Assessments. https://cfpub.epa.gov/ncea/iris_drafts/AtoZ.cfm (accessed 1 November 2019).

United States Environmental Protection Agency (U.S. EPA) (2017b). Volatile Organic Compounds' Impact on Indoor Air Quality. https://www.epa.gov/indoor-air-quality-iaq/volatile-organiccompounds-impact-indoor-air-quality (accessed 7 October 2019).

World Health Organization (WHO) (1989). Indoor air quality: Organic pollutants. Environ. Technol. Lett. 10, 855-858. https://doi.org/10.1080/09593338909384805

Wu, F., Yu, Y., Sun, J., Zhang, J., Wang, J., Tang, G., Wang, Y. (2016). Characteristics, source apportionment and reactivity of ambient volatile organic compounds at Dinghu Mountain in Guangdong Province, China. Sci. Total Environ. 548-549, 347-359. https://doi.org/10.1016/j.s citotenv.2015.11.069

Xie, Y., Berkowitz, C.M. (2006). The use of positive matrix factorization with conditional probability functions in air quality studies: An application to hydrocarbon emissions in Houston, Texas. Atmos. Environ. 40, 3070-3091. https://doi.org/10.1016/j.atmosenv.2005.12.065

Xiong, Y., Du, K. (2020). Source-resolved attribution of ground-level ozone formation potential from VOC emissions in Metropolitan Vancouver, BC. Sci. Total Environ. 721, 137698. https://doi.org/10.1016/j.scitotenv.2020.137698

Xiong, Y., Bari, M.A., Xing, Z., Du, K. (2020). Ambient volatile organic compounds (VOCs) in two coastal cities in western Canada: Spatiotemporal variation, source apportionment, and health risk assessment. Sci. Total Environ. 706, 135970. https://doi.org/10.1016/j.scitotenv.2019.135 970

Xuan, L., Ma, Y., Xing, Y., Meng, Q., Song, J., Chen, T., Wang, H., Wang, P., Zhang, Y., Gao, P. (2021). Source, temporal variation and health risk of volatile organic compounds (VOCs) from urban traffic in Harbin, China. Environ. Pollut. 270, 116074. https://doi.org/10.1016/j.envpol. 2020.116074

Yang, Y., Ji, D., Sun, J., Wang, Y., Yao, D., Zhao, S., Yu, X., Zeng, L., Zhang, R., Zhang, H., Wang, Y., Wang, Y. (2019). Ambient volatile organic compounds in a suburban site between Beijing and Tianjin: Concentration levels, source apportionment and health risk assessment. Sci. Total Environ. 695, 133889. http://doi:10.1016/j.scitotenv.2019.133889

Zhang, H., Li, H., Zhang, Q., Zhang, Y., Zhang, W., Wang, X., Bi, F., Chai, F., Gao, J., Meng, L., Yang, T., Chen, Y., Cheng, Q., Xia, F. (2017). Atmospheric volatile organic compounds in a typical urban area of Beijing: Pollution characterization, health risk assessment and source apportionment. Atmosphere 8, 61. https://doi.org/10.3390/atmos8030061

Zhang, J., Sun, Y., Wu, F., Sun, J., Wang, Y. (2014). The characteristics, seasonal variation and source apportionment of VOCs at Gongga Mountain, China. Atmos. Environ. 88, 297-305. https://doi.org/10.1016/j.atmosenv.2013.03.036

Zhang, R., Cohan, A., Pour Biazar, A., Cohan, D.S. (2017). Source apportionment of biogenic contributions to ozone formation over the United States. Atmos. Environ. 164, 8-19. https://doi.org/10.1016/j.atmosenv.2017.05.044

Zhang, X., Yin, Y., Wen, J., Huang, S., Han, D., Chen, X., Cheng, J. (2019). Characteristics, reactivity and source apportionment of ambient volatile organic compounds (VOCs) in a typical tourist city. Atmos. Environ. 215, 116898. https://doi.org/10.1016/j.atmosenv.2019.116898

Zhang, Z., Wang, X., Zhang, Y., Lu, S., Huang, Z., Huang, X., Wang, Y. (2015). Ambient air benzene at background sites in China's most developed coastal regions: Exposure levels, source implications and health risks. Sci. Total Environ. 511, 792-800. https://doi.org/10.1016/j.scitot env.2015.01.003

Zhao, Q., Li, Y., Chai, X., Xu, L., Zhang, L., Ning, P., Huang, J., Tian, S. (2019). Interaction of inhalable volatile organic compounds and pulmonary surfactant: Potential hazards of VOCs exposure to lung. J. Hazard. Mater. 369, 512-520. https://doi.org/10.1016/j.jhazmat.2019.01.104

Zheng, H., Kong, S., Yan, Y., Chen, N., Yao, L., Liu, X., Wu, F., Cheng, Y., Niu, Z., Zheng, S., Zeng, X., Yan, Q., Wu, J., Zheng, M., Liu, D., Zhao, D., Qi, S. (2020). Compositions, sources and health risks of ambient volatile organic compounds (VOCs) at a petrochemical industrial park along the Yangtze River. Sci. Total Environ. 703, 135505. https://doi.org/10.1016/j.scitotenv.2019.135505 